\title{
Chapter 14 \\ Collectivist Ideals and Soviet Consumer Spaces: Mikrorayon Commercial Centres in Vilnius, Lithuania and Tallinn, Estonia
}

\author{
Matas Šiupšinskas and Epp Lankots
}

\begin{abstract}
This chapter focuses on Soviet mikrorayon centres-multifunctional social, and commercial centres - built in large housing estates in Vilnius, Lithuania and Tallinn, Estonia from the 1960s to the 1980s. In both countries, ensuring proper services to modern citizens was initially based on the conceptual model of a multistage domestic service system with small shops integrated into the urban fabric next to homes, and larger mikrorayon centres with self-service supermarkets reachable by foot without crossing wide roads. Mikrorayon centres also represented a novel type of urban space. New pedestrian commercial centres, influenced by the Vällingby centre in Stockholm and Tapiola centre near Helsinki, operated as a simulation of traditional city centres in sparse, freely planned new settlements. We argue that the theoretical model of multistage domestic services, as well the ideological and communal mission of the centres, was quickly reworked into a type of space that embraced consumption and individual behaviour within the framework of collectivism. The study shows how the architectural form and visual aesthetic of the centres had a specific role in this. As such, the Soviet mikrorayon centres were the product and defining part of the hybrid nature of late Soviet society and represent a peculiar type of spatiality where conflicting value systems do not exclude each other but instead interact.
\end{abstract}

Keywords Housing estates - Mikrorayon centres • Soviet modernism • Late-socialist architecture

\footnotetext{
M. Šiupšinskas $(\bowtie)$

Department of History, Vilnius University, Vilnius, Lithuania

e-mail: mr.matas@gmail.com

E. Lankots

Institute of Art History and Visual Culture, Estonian Academy of Arts, Tallinn, Estonia e-mail: epp.lankots@artun.ee

(C) The Author(s) 2019

D. B. Hess and T. Tammaru (eds.), Housing Estates in the Baltic Countries,

The Urban Book Series, https://doi.org/10.1007/978-3-030-23392-1_14
} 


\subsection{Introduction}

The post-war decades through the mid-1970s were the worldwide golden age of new towns and mass-produced housing estates. The biggest urban utopian movement of the twentieth century introduced new habitation models in vast homogeneous housing estates that brought about changes in everyday routines including household provisioning. During the 1970 s, new social and commercial centreswhere residents could socialise and find most necessary services and goods - were planned in the mikrorayons of pre-fabricated housing estates in the Baltic countries. In order to develop a network of services, a multistage domestic service system was introduced in Lithuania, Latvia and Estonia, with small shops integrated into the urban fabric next to homes, and larger mikrorayon centres reachable by foot without crossing wide roads. Mikrorayon centres also represented a novel type of urban space. New pedestrian commercial centres operated as a simulation of traditional city centres in sparse, freely planned new settlements. Their architectural form combined with commercial signs on the facades, etc., helped to create a specific sense of belonging. The mikrorayon centres like ABC-5 in Tallinn, Žirmūnai in Vilnius, Imanta and Minsk in Riga, and several other shopping centres across the Soviet Union became symbols of new urban life and received publicity in architectural and propaganda press (Deveikienè 1980; Gaižutis and Grubevicius 1985; Ikonnikov 1975; Orentaite 1977; Pangsepp and Korp 1978; Tomberg 1975; Минкявичюс 1987; Страутманис et al. 1987).

This study focuses on mikrorayon centres built in post-war mass housing estates in Lithuania and Estonia, specifically Lazdynai and Šeškinè in Vilnius and Mustamäe in Tallinn. We argue that the theoretical model of multistage domestic services, as well the ideological and communal mission of the centres, was quickly reworked into a hybrid type of space embracing consumption and individual behaviour within the framework of collectivism.

Consumerism in the Soviet Union did not only appear on the symbolic level (like human desires or visual representation) but arose as a new direction in Brezhnev's party policy in the 1970s (Chernyshova 2013, 2016; Paretskaya 2012). Prime Minister Aleksei Kosygin had indicated the importance of accumulating reserves of consumer goods when he introduced economic reform in 1965. Likewise, Brezhnev declared during the Congress of the Communist Party in 1971 that Soviet citizens no longer had to sacrifice material comfort, and, with the promise of an abundance of consumer goods he indicated the replacement of the former ascetic discourse with a more consumer-oriented one, as depicted in Fig. 14.1 (Paretskaya 2012). To improve production efficiency, the government was offering workers material incentives (among other things) in the form of increased wages and rewards (Harrison 2002). In order to prove efficient, these incentives had to be matched by better stocked shops (Chernyshova 2016).

This chapter examines Soviet mikrorayon centres as historically and culturally situated spaces, suggesting that the modernist centres were the product and defining part of the hybrid nature of late-socialist society, imbued as it was with 

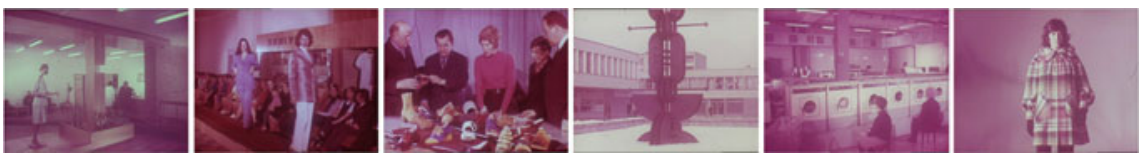

Fig. 14.1 Films promoting service centres in Lithuania. Stills from the movies 'I žiburèli', 'Juzè žengia per Lietuvą' and 'Sostinès servisas', 1970s. Created by Nota Liubošic in 1973 at Lietuvos kino studija. Source Lietuvos kino centras, used with permission

controversies and consistent ideological appropriations. Buildings and the built environment serve as important epistemological vehicles, therefore visual/ architectural material (including photos, plans, architectural sketches and drawings, etc.) form a primary source material for our research. Additional sources include archival material, brochures and propagandist picture albums. The wider meaning of the phenomenon of mikrorayon centres as Soviet consumer spaces emerges when placing the material in the context of general intellectual discussion and scholarly research on the late-socialist period in historical and cultural studies (see Yurchak 2006; Fürst 2010; Klumbyte and Sharafutdinova 2012; Chernyshova 2013; Feinberg and Kalinovsky 2016).

\subsection{From Neighbourhood Planning and ABC Towns to Soviet Mikrorayon Centres}

The first freely planned mass housing districts in the Soviet Union were drafted and planned in the second half of the 1950s - the experimental quarter of Novye Cheremushki in Moscow built between 1956 and 1958 being the first one-while the production lines of housing plants were running at full capacity from the $1960 \mathrm{~s}$ onwards. The new planning ideology introduced a unit-based approach at every scale. The planning of the whole districts and its constitutive micro-districts (known as mikrorayons in the Soviet Union), with schools, kindergartens, shops, primary services and entertainment facilities, were planned for 5000-10,000 residents. Small flats were organised according to a square metre-based standard of living space per person.

The roots of Khrushchëv's city planning policy branched in various directions: it contained both pre-Second World War Russian avant-garde ideas about urbanisation with the building as the social container (Charley 2004), as well as Western concepts which linked the concepts of garden cities and Clarence Perry's work on the neighbourhood unit (Perry 1929), the functional zoning of the city according to CIAM principles and state-subsidised development of social structures (Ojari 2004). Although Perry's reforms in city planning had some currency in the 1930s, they became the core of the "return to order" on both sides of the block in the post-war reconstruction years (Wakeman 2016). Yet there was a clear difference in emphasis. While the bedrock for social life in Western new towns was the young 
nuclear family, the homogenous, yet diffuse urban qualities of mikrorayons and small flats with existenzminimum kitchens served the ideals of (class) collectivity in the Soviet Union while preventing group differentiation and withdrawal into family privacy. However, in both Western and Soviet contexts, modernist mass housing estates could be considered as a strategy of political stabilisation (Ojari 2004; Wakeman 2016).

The first direct source from which Soviet city planning obtained theoretical examples was the International Union of Architects (UIA) Congress, held in Moscow in 1958, on the theme of reconstructing cities (Ojari 2004). The congress and the active cultural exchange that started in the late 1950s and included numerous architects' study trips to Finland, Sweden, England, etc., and subscriptions to Western architectural and planning journals in libraries, suggests that the principles of Soviet town planning were largely based on 'ready-made' examples. The design model of that time was the planning of Greater London in 1944, and in the Baltic republics, the Swedish and Finnish planning practices were especially influential.

An important source for planning local mikrorayon centres in the Soviet Union were ABC towns, a model which arose in Sweden in the 1950s. Arbete, Bostad, Centrum ('work, living, centre'), as it was known in Swedish, referred to a multifunctional satellite city that combined housing with workplaces and a local centre. The principle of ABC towns was first formulated by Sven Markelius in 1945, who applied the housing scheme in the spirit of British New Towns that featured diverse housing centred around a local centre (Poom 2005; Rudberg 1998). The idea was first put into practice in the Vällingby residential district (1950-1954, architect Sven Markelius) in western Stockholm. The Vällingby centre (1953-1955, architects Sven Bäckström and Leif Reinius) was also the first district centre in Northern Europe to introduce the commercial pedestrian precinct based on the model of Lijnbaan in Rotterdam (built 1948-1953). Vällingby fostered a building ideology based on the enthusiasm for collective living, which sprouted in 1930s Sweden. Even so, Vällingby remained an experiment. Providing sufficient work opportunities turned out to be a real problem as the distance from Stockholm-the main attraction in the region — was too small (Poom 2005). Farsta — the next satellite city that came out of Markelius' desk - was already a BC town ('Bostad, Centrum') in essence, as the residents worked in the city while the district centre mainly included commercial uses similar to North American shopping malls (Rudberg 1998).

The Swedish ideal of collective living — based on the idea of equality, according to which everybody was to be guaranteed equally high living standards-was more appropriate for the Soviet housing ideology than the Dutch or English models, which mainly involved building social housing that in the long run produced serious problems of segregation (Ико́нников 1978). Beyond a doubt, Vällingby, together with the Tapiola centre near Helsinki (design 1953-1955, completed 1961, architect Arne Ervi) that repeated the spatial and functional solution of the former, had an iconic position in the Soviet Union, and they were often reproduced in Soviet architectural literature published during the 1960s and 1970s (Васильев 1960; Васильев et al. 1958; Ико́нников 1967; Ико́нников 1978). These two 
housing estates, especially Tapiola, were frequently visited in the 1960 s by Estonian, Latvian and Lithuanian architects, and thus became the most significant model for mikrorayon centres in new housing estates in the Baltics (Bruns 1961; Drèmaitė et al. 2012; Hallas-Murula 2005; Mirov 1965; Mačiulis 2008; Ojari 2004; Väljas 2016).

While the Vällingby and Tapiola centres served as architectural role models for mikrorayon centres, the idea of self-service supermarkets became topical in the Soviet Union after Khrushchëv's visit to the United States in 1959. The rationalising impetus behind opening self-service supermarkets (universams) in the Soviet Union was similar to the retail trade in the capitalist economies: savings on staff costs and more efficient and quicker shopping for larger amounts of goods by the consumer. Yet, the phenomenon of supermarkets was more about a transnational transfer of culture and practice rather than an Americanisation of shopping, as retail experts from Eastern Europe also gathered knowledge about self-service and supermarkets during the trips to West Germany, Switzerland and Sweden (Trentmann 2012).

For the functional planning of the mikrorayon centres, the scientific organisation of service provision became a part of the technocratic rhetoric at that time. Experts were responsible for selecting how to organise supply and how to plan service infrastructure. Everything was calculated, measured and divided into different hierarchical levels. Such an approach was used not only for mikrorayon planning, but for the whole city and even the country. For example, cities and towns were divided by importance (state significance, regional significance). Based on the size of the city and its level of importance, infrastructures of different sizes and typesi.e. hotels, theatres, service centres-were planned and financed. A similar approach was used when planning housing districts.

In the early 1960s, a 'multi-stage domestic service system' was used to designate subsidiary functions planned in the housing estates in Lithuania and Estonia (Arman 1963; Aronas 1969; Tippel 1963). The network of public services was organised by dividing service buildings into several levels as shown in Fig. 14.2. Kindergartens and nurseries, schools, self-service shops, bakeries, and stores selling household goods were considered services of everyday use. It was a requirement to ensure a quick and safe pedestrian route from housing to these service places. The second category with periodic use consisted of workers' clubs with theatre halls, cinemas, bank and post offices, hairdressing salons, universal shops, music and art schools, libraries, sport complexes, outpatient (poly) clinics, pharmacies, laundries and dry cleaners. These functions were usually grouped into mikrorayon centres, or main centres that were easily accessible by foot or by public transport (one or two stops) (Tippel 1963; Vanagas 2008). The third group included institutions, enterprises and cultural buildings, which were usually concentrated in the city centre and accessible from the districts' transport nodes in half an hour by using public transport.

In essence, the multiple stages of domestic services meant the planning of services according to the primary and secondary needs on the district or micro-district scale (rayon and mikrorayon). For example, Lithuanian urbanist Jurgis Vanagas 
2.14 pav. Gyvenamosios zonos modelis, sudarytas pagal laips. nišką aptarnavimo sistemą:

1 - mikrorajon 4 centrai, 2 - gyvenamuju rajony centrai, 3-miesto centras, 4-pramonés rajono centras, 5- poilsio zonos centras, 6 specializuoti centrai

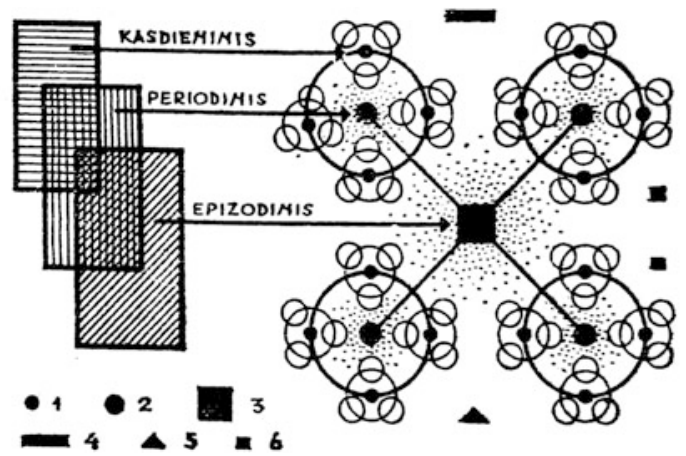

Fig. 14.2 Schematic of multistage domestic service system. Source Kazimieras Šešelgis, Rajoninio planavimo ir urbanistikos pagrindai, Vilnius: Mintis, 1975

described rayon as a territory composed of several mikrorayons, a park, a sport stadium and rayon centre with multistage domestic services (Vanagas 2008). A public or rayon centre was an important element, not only functionally but also compositionally: the main public space was located around it, often with representational symbols (a sculpture, a fountain or a square). The maximum distance from the most distant apartment building to the rayon centre could be $800-1000$ metres and 400-500 metres from the mikrorayon centre (Vanagas 2008). Of course, such a strict division was possible only in theory and in locations where topography is quite simple. In reality, the rayon centres were in many cases never realised (Mustamäe, Lazdynai) as the building efficiency proved too low. There was constant pressure to erect more residential buildings as the shortage of flats was not alleviated due to steady immigration, and there were not enough time and resources to spend on finishing all the planned subsidiary functions.

\subsubsection{Mikrorayon Centres in Vilnius-From Žirmūnai to Šeškine}

During the Soviet years, Vilnius became the main testing ground for local architects and planners. The housing needs of city professionals and industry workers was growing, the city was expanding and more people were coming from smaller towns to study or work. As an answer to the general housing problem, the first groups of panel housing (series No. 1605A) were erected in the Naujamiestis eldership (the smallest administrative division in Lithuania), and later in Antakalnis and other parts of the city (Mikučianis 2000). Žirmūnai, the first full-scale mass housing district in Vilnius and Lithuania, was constructed from 1962 to 1969. In 1964, a new series of panel houses (No. I-464) was introduced (Čerbulènas and Glemža 1985) and thus the construction of new housing blocks became completely 
standardised (Reklaitė and Leitanaitè 2011). Together with a new wave of mass housing districts, a multistage domestic service system was put into use in Lithuania after 1962 (Balčiūnas 1974). The first mikrorayon centre was built in Panevėžys, with more built later in Kaunas and Klaipeda (Aronas and Balčiūnas 1969). The mikrorayon centre of Žirmūnai, built in 1969, was the first one built in Vilnius (architects A. Aronas, V. Ivanova and A. E. Paslaitis) (Petrauskas 1966). The main elements of the complex were a commercial centre with shops on the ground floor, and a restaurant, universal hall and library on the second floor (Čerbulènas and Glemža 1985). Behind it was a separate block with a tailor's shop, hairdresser, savings office, post office and domestic services. It was extended to one side, making the composition more dynamic and asymmetrical. This type of complex with its slight facade and functional modifications was repeated three times in the Žirmūnai neighbourhood (the centres Žirmūnai, Minskas and Šaltinèlis), twice in Lazdynai (the centres Lazdynai and Erfurtas) and in other cities as well.

Žirmūnai featured a sculpture called "Joy” (sculptor Kazys Kisielis). The interior of the post office was decorated, as was a restaurant where sculptor Teodoras Kazimieras Valaitis created an abstract mural from copper (Petrauskas 1966). All the attempts to decorate the centre show its role as a representational space for the district. A similar approach was implemented in other centres. For example, the most iconic pictures of the Lazdynai and Žirmūnai neighbourhood were taken in mikrorayon centres where the urban space was decorated with water ponds and sculptures, and was connected to pedestrian walkways as shown in Fig. 14.3. The restaurants located on the second floor of mikrorayon centres in Lazdynai and Žirmūnai were promoted as modern, fancy and desirable places and were photographed for albums and tourist brochures. Buildings and sculptures next to mikrorayon centres were part of the symbolism of new, modern Vilnius used for souvenirs.

The reason for such extensive publicity was partly because both Žirmūnai and Lazdynai were awarded for their designs. In 1968, the designers (architects Birute Kasperavičienè, Bronislovas Krūminis, engineers Vaclovas Zubrus and Smuelis Liubeckis) of the Žirmūnai central mikrorayon received the USSR State Prize and in 1974 the designers of Lazdynai (architects Vytautas Čekanauskas, Vytautas Brèdikis, Vytautas Balčiūnas, Gediminas Valiuškis and engineers Algimantas Kleinotas and Vincentas Šileika) were awarded the Lenin Prize. It was the first time a mass housing district received such recognition. As a neighbourhood influenced by Scandinavian examples (e.g. Tapiola), Lazdynai was presented as an example of how local architects were able "to subtly protect the beauty of nature and to find a harmonious relation between building volumes and the topography of the place" (Vileikis 1986, p. 45). Compared to Mustamäe in Tallinn, Lazdynai covers almost an equal area, but was planned for a much smaller population. In Lazdynai, the buildings were placed between the pine trees, while in Mustamäe the final configuration of the mikrorayons was determined by the logic of moving the cranes around the construction site (Kalm 2001).

Lazdynai, a district for 30,000 inhabitants, was almost fully planned according to the requirements of a multistage domestic service system with all three stages in 


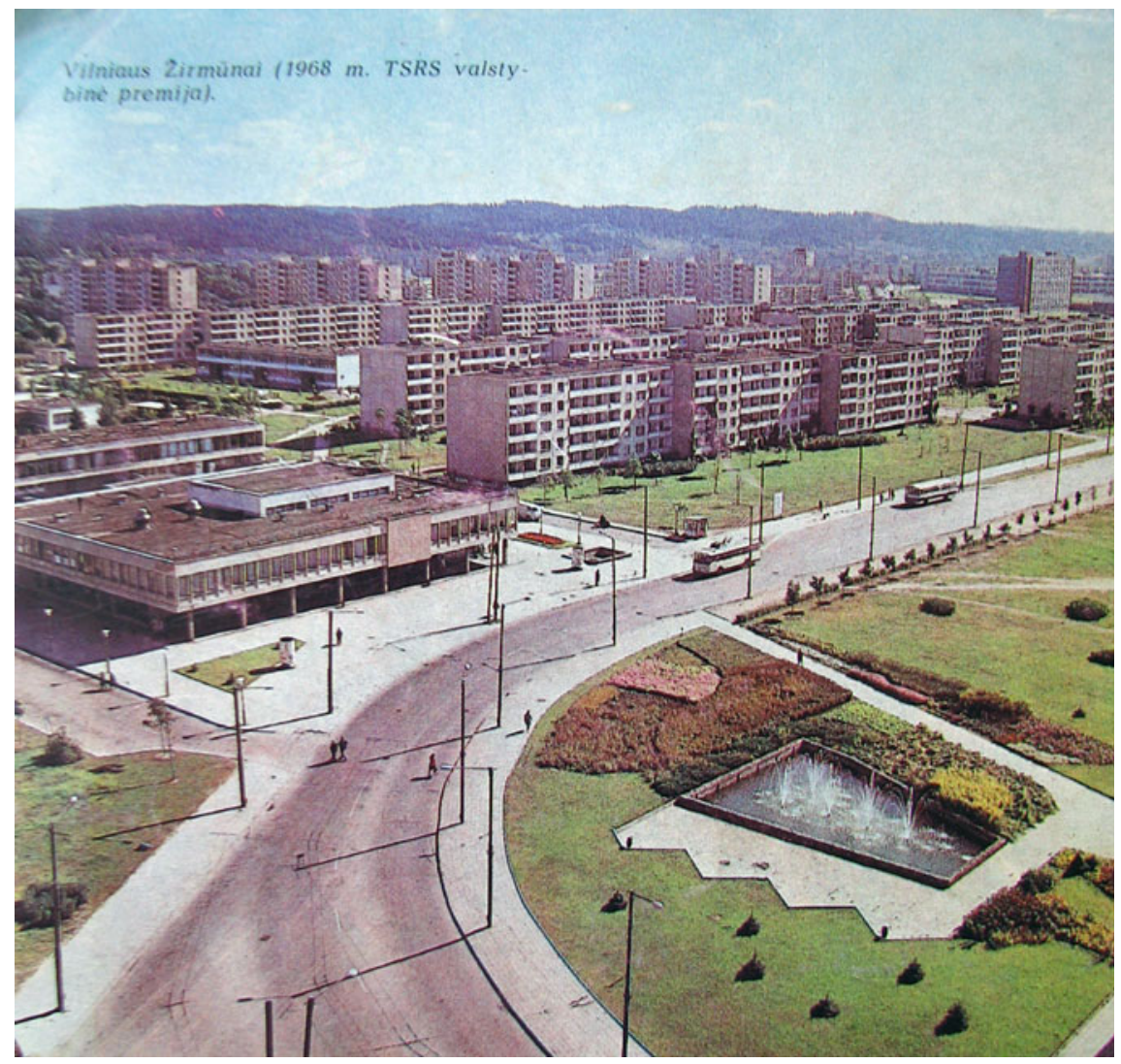

Fig. 14.3 Žirmūnai neighbourhood and the mikrorayon centre "Šaltinèlis", 1980s. Source Journal Statyba ir architektūra, used with permission

mind. Smaller shops were planned inside the neighbourhoods close to one's home, then bigger mikrorayon centres were planned next to inner micro-district streets, and finally, the main rayon centre (architect Česlovas Mazūras, 1966) was envisioned in the very middle of the whole housing area and close to public transport routes. Its impressive structure rising above the main road was reminiscent of the Vällingby centre, but it was too challenging and expensive to build so it was never realised (Grunskis and Šiupšinskas 2012). Two main mikrorayon centres (Erfurtas and Lazdynai) were built using modifications of the same standardised project as in Žirmūnai (standard project No. 3779_5). The third mikrorayon centre was replaced by housing blocks and the fourth one was a smaller and less elaborate building based on standard project No. LG 272-31-46, designed by architect Arūnas Eduardas Paslaitis (together with Aleksandras Aronas and engineer Maryte Kaklauskienè) (Buivydas 2000). It was almost a structuralist approach (Buivydas 2006) that consisted of several modular blocks with different functions. The 
modules made it possible to create multiple combinations or expand the centre in further stages (Balčiūnas 1970).

The multistage domestic service system that was used in Žirmūnai and Lazdynai looked nice in theory, though criticism began quite soon. First of all, it was hard to adapt standard projects to different needs and to use them together as one complex (Girčys 1971). Bigger commercial centres were often redesigned to fit a specific place, and that brought up the question of whether to use a standard project if it requires serious updates. At the same time, the theory on planning the locations of different services was already failing. First of all, the planners started to recognise that a mikrorayon is not a closed system and these centres are partly servicing other mikrorayons and housing districts (Girčys 1971). Second, it was more economical to maintain bigger centres rather than a number of smaller shops. Initially building smaller places of 'primary services' - where inhabitants could place their orders, use vending machines, and which contained a small canteen, meeting spaces, childrens' spaces and workshops - was attempted for different groups of houses (Aronas and Balčiūnas 1969). It was based on the idea that an individual apartment was used only for the most private of needs with all other services planned as communal.

However, this idea did not function as intended and the trend shifted towards more concentrated service centres. It was not only the planning that failed, but the distribution and the supply system, as well. Jokes about queuing next to a shop without knowing what they were selling were widespread. The dispersive domestic service system attracted more and more criticism over the years (Čaplikas 1987). For example, it was claimed that separate shops were too small and so it was hard to provide a full range of products which left customers with a limited choice. The most radical attempt to concentrate public functions appeared in the Šeškine district (built 1979-1985, architect Kazimieras Rimantas Balènas) (Bielinis 1988), where only one main rayon centre (built in 1981-1986, designed by multiple architects) was designed and built for all six mikrorayons and without any individual mikrorayon centres at all. Thus, the mikrorayon centres and separate service buildings were almost completely removed from the design.

The buildings in the Šeškinè centre were oriented towards the inside, where an internal square, shown in Fig. 14.4, with clock tower and a water basin were placed. The centre was planned as an organic urban structure that would change and evolve depending on needs (Mačiulis 2009). The idea of the building as a freestanding object in space was rejected, and designers tried to create a complex composition with shopping passages and elevated galleries with different levels of public space. The red brick, new triangular floor slabs and glued wood beams that were used in the designs were not easily available, which shows that the Šeškinè rayon centre was considered an important project. In its attempt to go beyond the usual practice of service centre design (Kulikauskas 1986), the project received a lot of attention and was awarded the Prize of the Council of Ministers of the USSR in 1987 (Reklaite and Leitanaite 2011). Despite the fact that the concentrated rayon centres built in Šeškinè and Justiniškès were considered successful practices to be 


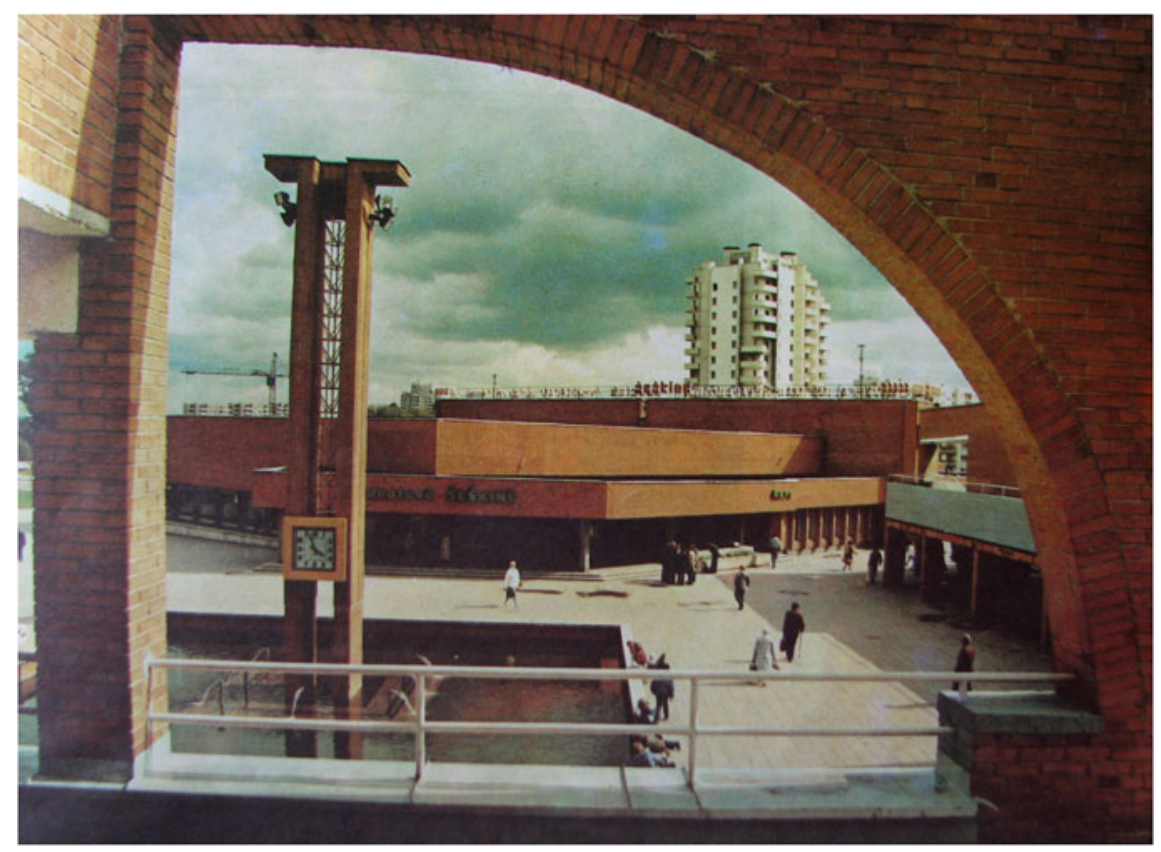

Fig. 14.4 Clock tower and fountain in the Šeškinè rayon centre, 1980s. Source Journal Statyba ir architektūra, used with permission

continued in future districts (Vèlyvis 1988), Pašilaičiai and Fabijoniškès were never fully completed because of ascendant political and economic changes.

The development of rayon and mikrorayon centres in Vilnius mark the transition from the theoretical and technocratic idea of a multistage domestic service system to more concentrated, bigger commercial centres where a greater variety of products and services were available. At the same time, it shows how different ideas from outside were shaping the value system of local professionals. Scandinavian modernism and planning practices were used as a progressive role model until the poor and limited local construction industry turned it into a cliché. Also, the priorities were slowly moving towards exceptional aesthetics and individuality.

\subsection{ABC Centres in Mustamäe and Other Housing Estates in Tallinn}

As in the general building history of the USSR, the story of mikrorayon centres in new residential districts in Estonia is similarly marked by changing and partly unrealised ideas. Mustamäe in Tallinn was one of the first modernist housing estates in the Soviet Union based on the ideas of free plan and pre-fabricated concrete 
construction. The competition for the area took place in 1958 (winning architects Voldemar Tippel, Lidia Pettai, Toivo Kallas and engineer Aleksander Prahm) and the building of the district that was planned for 60,000 inhabitants started in 1962 and lasted for ten years. In the 1970s, Väike-Õismäe (planned in 1968 by Mart Port and Malle Meelak), a district for 40,000 inhabitants based on the idea of a circular town, was built. The third large housing estate in Tallinn, Lasnamäe (master plan 1970-1976 by Mart Port, Malle Meelak et al.) was established for 200,000 inhabitants and would be divided into 11 double-size mikrorayons (with 12,000 18,000 people each) with large centres located near the thoroughfare with pedestrian overpasses and stops for public transport. Several of Lasnamäe's new planning ideas and none of the mikrorayon centres were completed as intended.

In terms of architectural history, Mustamäe mikrorayon centres are important as they set a model for a whole new building typology and corresponding architectural aesthetic in Estonia. Similar low-rise supermarkets with cubic volumes and glass walls covered with horizontal roof plates and projecting cornices were erected during the 1970s and the early 1980s in several Estonian cities and kolkhoz settlements in the countryside. In 1966, the plan for the public houses in Mustamäe prescribed the functional and spatial use of the centres that provided a vision of the routine and lifestyles of Soviet citizens. By 1966, the first mikrorayons were completed, emphasising shortcomings in services and architectural solutions that in turn led to a decision to abandon the idea of the so-called separate pavilions of primary services and instead integrated different functions. These included grocery and household stores, services (shoe repair, laundry, hairdresser, etc.), as well as ideological education and social activities (the so-called "red corners"). The design of the mikrorayon or the so-called ABC centres was part of the detailed planning and building process of mikrorayons, though the numbers (ABC-2, ABC-3, etc.) did not necessarily indicate the actual order of completion of mikrorayons or their centres. Completing the centres took altogether nearly 20 years. The main reasons were the forced construction of residential houses that pushed public buildings to the background and the shortage of materials and different resources that resulted in a loss of building capability in the 1970s.

Initially planned as standardised buildings, the ABC centres were nevertheless built according to individual designs. Their common visual and architectural identity was constructed through a recognisable spatial and visual form: a compact public space surrounded by low-built volumes, and pedestrians moving between different shops and services (food and everyday products, culinary or takeaway food, hairdressers, shoe makers, photo studios, dry cleaning shops, the municipal housing office, as well as different social functions like a universal hall used for sports or gatherings, a café or a restaurant). Their architectural vocabulary included rational form, and the buildings were fitted with red brick facades covered with flat roofs with wide overhanging cornices. The facades adjoining the pedestrian precinct had huge windows, so walking by was similar to passing a shop window in traditional urban centres. The main public area was decorated with a pool or fountain, or an abstract sculpture in some cases. The new urban collective life was to be fully epitomised in a new centre for the entire Mustamäe district (the 1964 
competition was won by Toivo Kallas and Raine Karp, with the final design made by Raine Karp in 1972). It was planned to house, in addition to everyday services and shops, a 1000-seat cinema, a dance club, and various eating establishments from diners to restaurants. In the spirit of commercial centres in Vällingby and Tapiola housing estates, the composition of the winning design for Mustamäe emphasised the contrast of low-rise buildings in the shopping centre with a tall adjoining tower block. Various staircases provided access to multilevel vertical spatial arrangements, and covered inner courtyards formed compact, self-contained urban spaces (Mustamäe elamurajooni ühiskondliku keskuse projektide võistlusest 1965; Ojari 2000).

As the main district centre was planned in a neighbouring area at the same time, only the small, primary service pavilions were built in the first two mikrorayons (No. 1 and No. 3) in Mustamäe. The first multifunctional social and commercial centre in Mustamäe was built in the mikrorayon No. 2; it had a low rectangular U-shaped volumetric solution with a brick-façade and a flat roof with a wide, dark painted cornice-elements influenced by Scandinavian modernism that would prevail in later ABC centres. There was a grocery store (not a self-service supermarket yet), different services and a restaurant as well as a house of games-a bigger hall serving as the communal gathering spot and housing different events and activities for children and adults. The first ABC-centre was an oasis to some extent, although the open area leading to one of the main streets in Mustamäe did not permit a more enclosed space as in the centres designed later. ABC-4 (1965-1969, architects Paula Koido, Enno Talgre), shown in Fig. 14.5, contained the first supermarket built in Tallinn and it also was the first centre to be named an ABC centre. The layout has an exceptionally outgoing character, resembling a classic urban living quarter: various sections of buildings are placed with their 'backs' together, forming in this case a closed technical courtyard inside the 'quarter' while leaving the public area scattered along the perimeter of the whole complex.

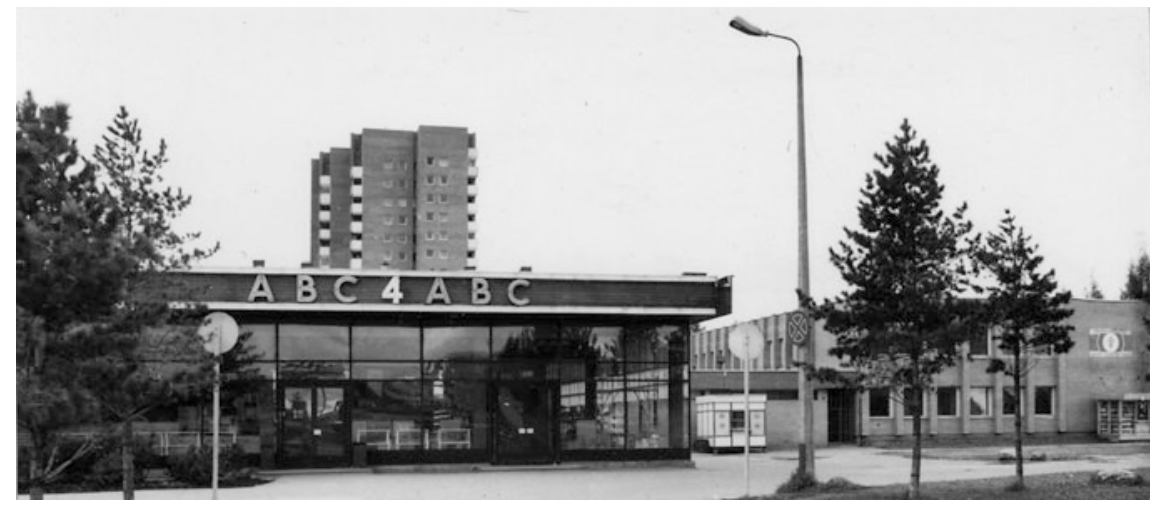

Fig. 14.5 ABC-4 in Mustamäe, Tallinn. Architects Paula Koido and Enno Talgre, built 19651972. Photo from the 1980s. Source Museum of Estonian Architecture, used with permission 
The visual and architectural parameters of $\mathrm{ABC}$ centres reached their height with ABC-5 (1963-1970, architect Peep Jänes), considered to be the most representative one in Soviet Estonia. Wide stairs placed on a sloping terrain led from a bus stop on a main street to a busy pedestrian area lined by low buildings placed freely under flat roof 'plates'. The centre was comprised of different stores (food, household, culinary), services, a universal hall and a famous restaurant Kännu Kukk. The outer perimeter of the centre had blind brick walls and emphasised the idea of an enclosed island in the midst of a monotonous built environment. The inner urban street, with open glass walls and its consumer aesthetics with different signs (bread, milk, gastronomy, etc.), shown in Fig. 14.6, invited social interaction.

A new approach to urban life in Mustamäe can be seen in ABC-6 (designed 1968, completed in the early 1980s, architect Miia Masso), which was probably the first building in Estonia to play with the Team-X idea of multilayered urban space and life on various levels. ABC- 6 is a complete structure that contains a complicated organism. The lower volume of the supermarket intersects with the higher volume of the services building, where smaller shops and workshops are located on an open shopping street, which is on the upper level of the building.

ABC-8 (1970, architects Tiiu Argus and Vivian Lukk), continued the motif of a building raised on a slope, as in the case of $\mathrm{ABC}-5$, yet here the one-directional elongated low structure formed a public area in front of the building enhanced by pine trees, a pool and a sculpture. The open public area in front of the building was, likewise, one of the main features of two later and smaller ABC centres (ABC-3,

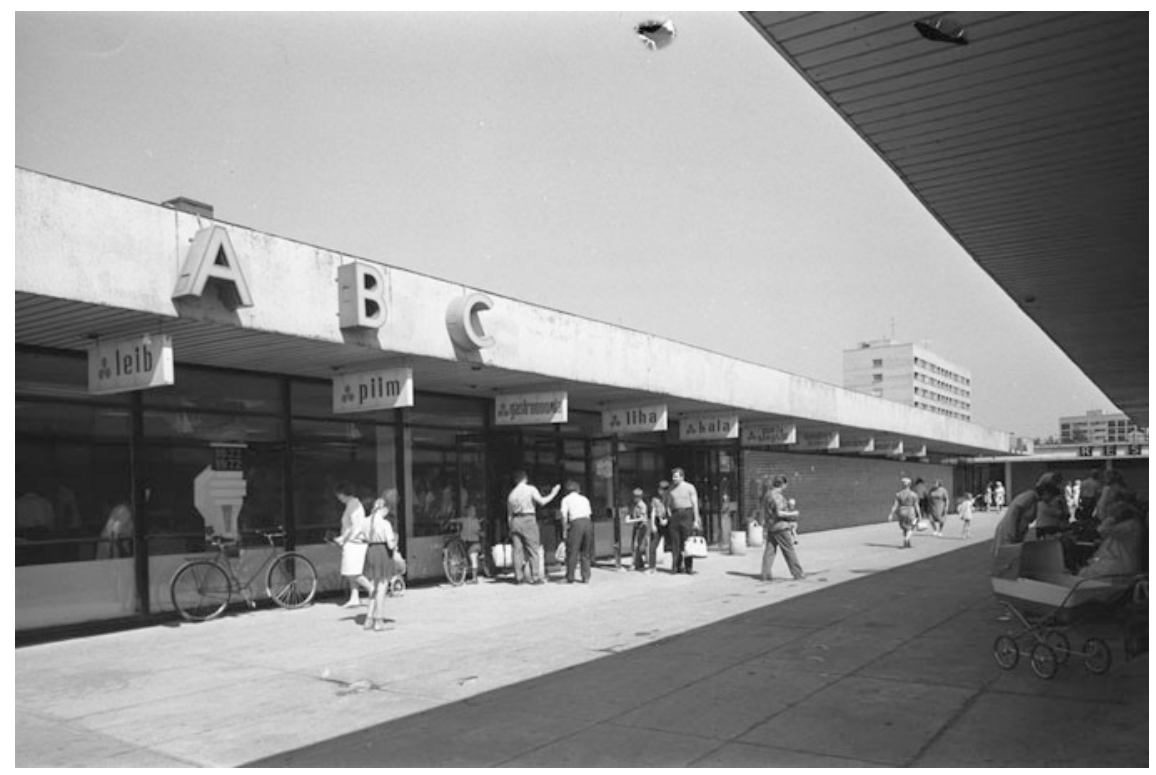

Fig. 14.6 Pedestrian area of ABC-5 in Mustamäe, Tallinn. Architect Peep Jänes, built 1963 1970. Photo by J. Budakov (1972). Source Estonian Film Archives, used with permission 
ABC-7) that were architecturally less impressive than the earlier ones. As the next mass housing estate built in Tallinn, Väike-Õismäe, was one large macro-district instead of several micro-districts, three smaller social and commercial centres were planned in the area-Õismäe-1 (1975, architect Lembit Aljaste) being the most representative one. The architectural aesthetic, as in the first mikrorayon centre in Lasnamäe (1978, architect Helje-Reet Aurik), was derived from Mustamäe's ABC centres that by the end of the 1970s was aesthetically outdated. The next supermarkets in Lasnamäe, built in mikrorayons No. 2 and No. 3 (named Kotka and Leningrad, respectively) and both designed by Lembit Aljaste in the early 1980s, introduced a new architectural logic. As they were meant to be part of the large mikrorayon centres stretched on both sides of the main traffic artery bridged by pedestrian overpasses and marked by adjoining tower blocks, as depicted in Fig. 14.7, their more compact yet more massive architectural solution derived from the idea of a complex urban nodal point that is accessible from different levels. Although none of the mikrorayon centres was completed as planned in Lasnamäe, the idea of large centres - double the size of Mustamäe's ABC centres - introduced a new approach to planning services in the district. The three-stage domestic service model was considered to be out of date when planning Lasnamäe, and the concept of a 'functional service scheme' was introduced instead (Meelak 1976). This meant that periodic services like the cinema, library, sauna, clubhouse, etc., were brought into the mikrorayon centre. The new approach retained the 500-m service radius and increased the number of inhabitants in the mikrorayon to 18,000. This, in turn, meant planning fewer but larger centres that would help to lower the costs and at the same time enlarge the assortment in the shops and introduce new services (Meelak 1976).

The designs for ABC centres and other mikrorayon centres, as well as the actual built and visual environment in Mustamäe, Väike-Õismäe and Lasnamäe, illustrate not only the transformation and shifting emphasis of neighbourhood planning ideas in Estonia, but also the imagery and changing scenery of urban practices like shopping and socialising.

\subsection{Conclusion: Mikrorayon Centres Function as Soviet Consumer Spaces}

The mikrorayon centres in Lithuania and Estonia connected with changes in lifestyle that emerged on the level of simple everyday habits and routine, e.g. buying food products in self-service shops. The centres were the first to introduce self-service supermarkets in Estonia and one of the first in Lithuania where all food and household products could be purchased from one place instead of a series of small specialty shops. In addition to everyday changes, the transformative role of the mikrorayon in Estonian and Lithuanian centres can be seen on the level of 


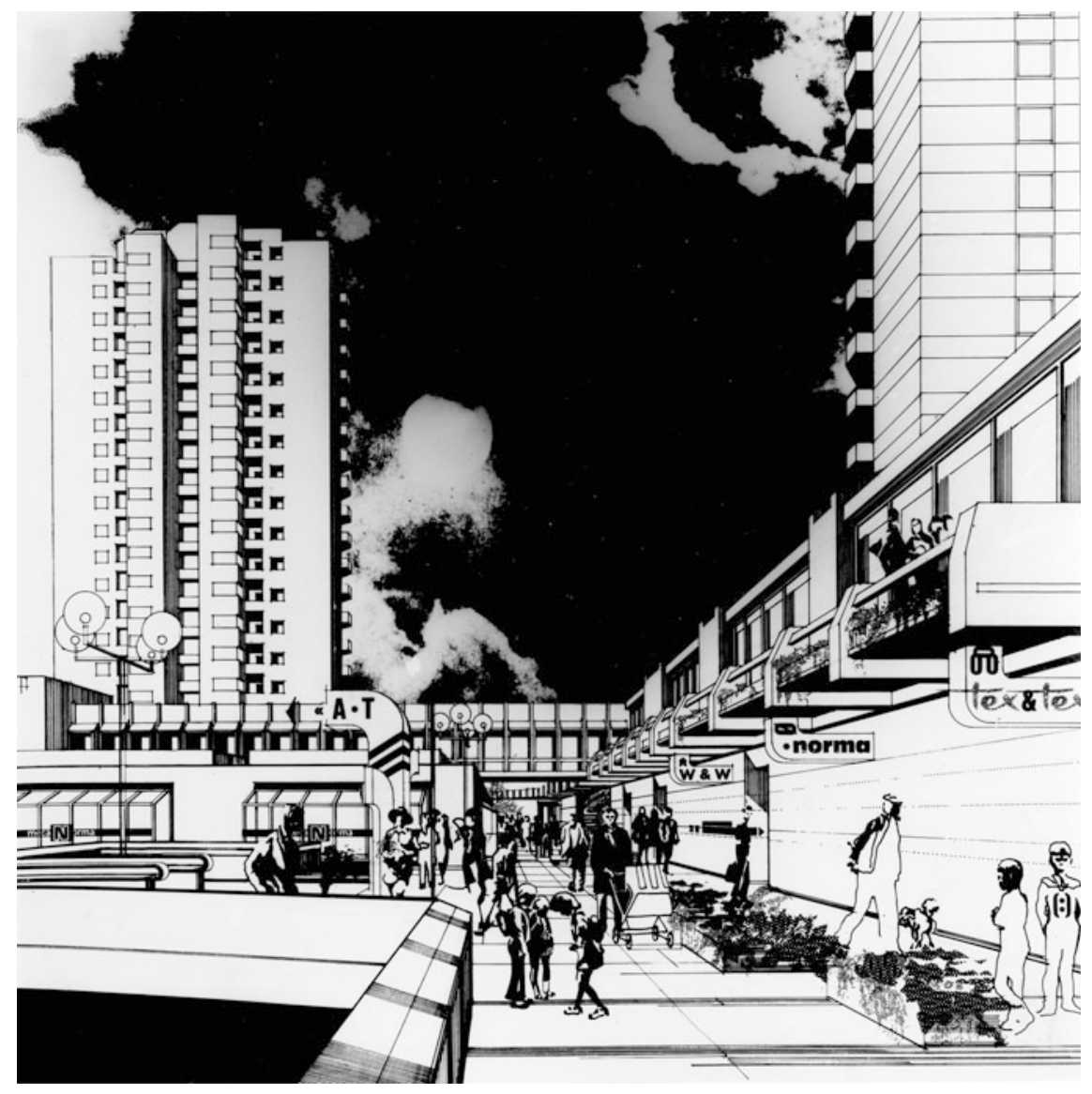

Fig. 14.7 Mikrorayon centre in Lasnamäe, Tallinn. Drawing by Mart Port. Source Museum of Estonian Architecture, used with permission

representation: architecture, urban landscape design, as well as specific building materials (e.g. red brick), had a specific importance in image creation.

In both countries, ensuring proper services to modern citizens was initially based on the conceptual model of a multistage domestic service system. Thus, the differences between the two cities appear on architectural rather than ideological grounds. In Vilnius, the construction of the first centres in Žirmūnai and Lazdynai was in accordance with the demands of industrialisation and rationalisation, as they were built according to standard designs based on module systems, while all the centres in mass housing estates in Tallinn used individual designs that were influenced by organic Scandinavian modernism. The Scandinavian influences appeared in Vilnius in the planning schemes and general milieu (e.g. Lazdynai), as the architectural solutions of mikrorayon centres applied more functionalist and structuralist approaches. The aura of novelty that surrounded the newly built centres 
in Tallinn in the late 1960s and early 1970s was not so much about architectural innovation, but was rather due to the whole new approach to the everyday living environment and the fact that the architectural aesthetics that were known from exceptional public buildings (e.g. the Helsinki-Tallinn Ferry Terminal or the Flower Pavilion) were brought into the everyday environment. By the late 1970s, Scandinavian modernism was already obsolete, and the centres in Väike-Õismäe are examples of a stereotypical approach in supermarket design. The 1980s marked a shift in the architecture of mikrorayon centres that were perhaps more evident in Vilnius. The Šeškinè centre was exceptional in rethinking the idea of a communal service building and the practice of shopping with novel structural solutions, while the mikrorayon centres built in Lasnamäe in Tallinn merely illustrate the shortcomings of the new paradigm that tried to go beyond the three-stage domestic service system.

Despite these different architectural specificities, the mikrorayon centres in both cities differ from the unified industrial appearance of district apartment buildings, and as such acquired a symbolic function as urban signs. As there were no other meaningful places in the homogenous environment consisting of pre-fabricated housing, the centres, both architecturally and functionally different from the rest of the urban settlement, were also ascribed a new kind of meaning. The role of mikrorayon centres as locales of identity (i.e. places where people mentally anchor themselves) has emerged from the memories of the people living in Mustamäe at the time and who emphasise the role of $\mathrm{ABC}$ centres in their cognitive maps of the district (Lankots and Sooväli 2008).

Identity formation in idealistic spaces like Soviet mikrorayon centres is related to complex tension between the public and the private in a socialist state. One of the main differences between Soviet and capitalist consumer spaces, in spite of their common simulative urban qualities, was the visibility of their ideological content. Capitalist commercial spaces can be described as semi-public, urban-like spaces that seemingly allow the experience of freedom or sense of public place in an area controlled by private interests (Lahti 2003). In a communist state, consumer space, a public area in its essence, could be described as overtly ideological and prescribing collective behaviour but at the same time encouraging individuality on a symbolic level through architecture and visual aesthetics. David Crowley and Susan Reid (2002) have suggested the shifting meanings of public and private within socialism, where not only the private is contested by the public (e.g. tearing down fences in the historic areas of Tallinn and liquidating private courtyards), but also the public sphere took on various social meanings apart from ideological ones. Collective consumption that was detached from the direct political meaning of collectivity is one example. In reality, the consumer experience turned out to be somewhat different from the rhetoric of the party promise of the coming abundance of consumer goods. Yet, as Paretskaya notes, it was not the goods themselves that mattered but the lifestyles they represented and encouraged (Paretskaya 2012). Thus, we believe, the spatial features and visual aesthetics of the mikrorayon centres embody socialist consumer culture according to a specific logic that differs from Western consumer society. As Crowley notes: "What defines a modern 
[Socialist] consumer society is not access to consumer goods but knowledge of them. In this regard, the role of advertisements, magazines and other forms of publicity is key" (Crowley 2017). Although access to branded goods, fashionable clothes or luxury products, like cars, was limited, people were aware of the aesthetic codes which accompanied modern consumerism. Accordingly, 'socialist consumerism' across the Eastern Bloc was a phenomenon found largely in the realm of images rather than things (Crowley 2017).

As such, mikrorayon centres represent socialist spaces that go beyond an ideological understanding of space and are described by a shifting and multilayered interaction between spatial organisation, expression and use (Crowley and Reid 2002). Consequently, the mikrorayon centres - while marking the ideological programme and changing trajectories of planning thought and habitation modelsrepresent a peculiar type of spatiality where conflicting value systems do not exclude each other but instead interact. Mikrorayon centres, both in Lithuania and Estonia, were built as public collective spaces and at the same time, through architectural imagery and visual codes, encouraged individual behaviour and values based on consumption and self-determination. When correlating the social and economic transformations of the last 15 years, the symbolic and functional importance of the mikrorayon centres in Vilnius and Tallinn has changed considerably. Besides being inaccessible to car traffic or with limited parking possibilities, poor maintenance and a partially reconstructed and partially deteriorating physical state reflect the divided ownership of the buildings. Similarly, the new functional scheme containing stores like budget supermarkets, second-hand clothing stores, pawn shops and casinos are rather illustrative of their present marginal position. Yet, the marginalisation of $\mathrm{ABC}$ centres cannot automatically be related to the deficiencies of modernist housing estates, for which identities are in transition today. As school and kindergarten networks as well as health and medical services are well developed in these residential districts, housing estates still remain important living areas in Vilnius and Tallinn.

Today, new shopping centres with gyms, cinemas, restaurants and speciality shops have been built near the main roads leading through the housing estates and are making efforts to acquire not only the status of district centres, but function as attractive entertainment centres for a larger part of the city. The former mikrorayon centres have remained in use mainly by first-generation residents of the housing estates, who are now retired. Transformed shopping practices in Soviet mass housing estates illustrate the shift from fulfilling the primary needs of Soviet citizens to the lifestyle and entertainment practices of post-socialist society.

Acknowledgements The research was funded by the Estonian Research Council [grant no. IUT32-1]. 


\section{References}

Arman H (1963) Elamurajoonidest ja elamukompleksidest. Linnaehituse küsimusi Eesti NSV-s. Eesti NSV Ministrite Nõukogu Riiklik Ehituse ja Arhitektuuri Komitee, Tallinn, pp 31-36

Aronas A, Balčiūnas V (1969) Mikrorajonų visuomeniniai-prekybiniai centrai. Statyba ir architektūra 11:7-9

Balčiūnas V (1970) Naujas kompleksas miestų mikrorajonams. Statyba ir architektūra 11:1-3

Balčiūnas V (1974) Apie gyventojų aptarnavimo sistemas ir kompleksus. Statyba ir architektūra $2: 2-5$

Bielinis J (1988) Lietuvos TSR istorijos ir kultūros paminklų sąvadas 1. Vyriausioji enciklopedijų redakcija, Vilnius

Bruns D (1961) Tapiola. Eesti NSV arhitektuur. Artiklite kogumik. Riiklik Ehituse ja Arhitektuuri Komitee, Tallinn, pp 46-50

Buivydas R (2006) Architektūra: pozityvai ir negatyvai. Ex Arte, Vilnius

Čaplikas V (1987) Prekybos centrai Vilniuje. Klaidos kartojamos. Statyba ir architektūra 9:20-21

Čerbulènas K, Glemža J (1985) Vilniaus architektūra. Mokslas, Vilnius

Charley J (2004) The concrete memory of modernity: excerpts from the Moscow diary. In: Hvattum M, Hermansen C (eds) Tracing modernity: manifestations of the modern in architecture and the city. Routledge, London, pp 195-213

Chernyshova N (2013) Soviet consumer culture in the Breznev era. Routledge, London, New York

Chernyshova $\mathrm{N}$ (2016) Consumers as citizens: revisiting the question of public disengagement in the Brezhnev era. In: Feinberg D, Kalinovsky AM (eds) Reconsidering stagnation in the Brezhnev era: ideology and exchange. Lexington Books, Lanham, pp 3-20

Crowley D (2017) 'Consumer art' and other commodity aesthetics in Eastern Europe under communist rule. https://faktografia.com. Accessed 3 Oct 2017

Crowley D, Reid SE (2002) Socialist spaces: sites of everyday life in the Eastern bloc. Berg, Oxford, New York

Deveikienè O (1980) Vilnius. Mintis, Vilnius

Drèmaitė et al (2012) Architektūra sovietinèje Lietuvoje. Vilniaus dailès akademijos leidykla, Vilnius

Feinberg D, Kalinovsky AM (eds) (2016) Reconsidering stagnation in the Brezhnev era: ideology and exchange. Lexington Books, Langham

Fürst J (2010) Stalin's last generation: soviet post-war youth and the emergence of mature socialism. Oxford University Press, Oxford

Gaižutis A, Grubevičius A (1985) Vilnius. Mintis, Vilnius

Girčys G (1971) Dẻl prekybos objektų nomenklatūros. Statyba ir architektūra 12:6-8

Grunskis T, Šiupšinskas M (2012) Tarybinio laikotarpio viešujų erdvių transformacijos Lietuvoje. Vilniaus Žirmūnų ir Lazdynų atvejis. J Arch Urban 36:209-221. https://doi.org/10.3846/ 20297955.2012.732492

Hallas-Murula K (2005) Soome-Eesti: sajand arhitektuurisuhteid. Eesti Arhitektuurimuuseum, Tallinn

Harrison M (2002) Economic growth and slow-down. In: Bacon E, Sandle M (eds) Brezhnev reconsidered. Palgrave MacMillan, Basingstoke, pp 38-67

Ikonnikov A (1975) Soviet architecture of today: 1960s-1970s. Aurora Art Publishers, Leningrad

Kalm M (2001) Eesti 20. sajandi arhitektuur. Prisma Prindi Kirjastus, Tallinn

Klumbyte N, Sharafutdinova G (2012) Soviet society in the era of late socialism, 1964-1985. Lexington Books, Lanham

Kulikauskas P (1986) Šeškinès centras - bendravimas su žaviu kaprizingu vaiku. Statyba ir architektūra 6:10-12

Lahti J (2003) Tapionraitti - the backbone of the pedestrian precinct. In: Tuomi T (ed) Tapiola. Life and architecture. Building Information Ltd., Helsinki, pp 59-82

Lankots E, Sooväli H (2008) ABC-keskused ja Mustamäe mikrorajoonide identiteedid. Kunstiteaduslikke Uurimusi/Stud Art Arch 17(4):88-113 
Mačiulis A (2008) Permaningi metai. Architekto užrašai, Vilniaus dailès akademijos leidykla, Vilnius

Mačiulis A (2009) Kęstutis Pempè: architekto biografija. Archiforma 2:42-48

Meelak M (1976) Lasnamäe projekteerimistöödest. Ehitus ja Arhitektuur 2:12-17

Mikučianis V (2000) Noréjau dirbti Lietuvoje. Vilniaus dailès akademijos leidykla, Vilnius

Mirov B (1965) Arhitekti tähelepanekud Soome reisilt. Ehitus ja Arhitektuur 1:41-43

Mustamäe elamurajooni ühiskondliku keskuse projektide võistlusest (1965) Ehitus ja Arhitektuur $2: 31-37$

Ojari T (2000) Modernismi parameetrid: Mustamäe kujunemisest. In: Hallas K (ed) Kümme. Eesti Arhitektuurimuuseumi Aastaraamat. Eesti Arhitektuurimuuseum, Tallinn, pp 49-64

Ojari T (2004) Elamispind. Modernistlik elamuehitusideoloogia ja Mustamäe. Kunstiteaduslikke Uurimusi/Stud Art Arch 13(2):42-65

Orentaite B (1977) Vilnius. Mintis, Vilnius

Pangsepp R, Korp M (1978) Nõukogude Eesti. Eesti Raamat, Tallinn

Paretskaya A (2012) A middle class without capitalism? Socialist ideology and post-collectivist discourse in the late-soviet era. In: Klumbyte N, Sharafutdinova G (eds) Soviet society in the era of late socialism, 1964-1985. Lexington Books, Lanham, pp 43-66

Perry C (1929) The neighborhood unit: a scheme of arrangement for the family-life community. Regional Plan of New York and Its Environs, New York

Petrauskas J (1966) Visuomeninis prekybinis centras. Statyba ir architektūra 8:28

Poom J (2005) Housing policy in Sweden 1945-2000. In: Kalm M, Ruudi I (eds) Võistlevad õnned. Elukeskkond külma sõja sõja perioodil/Constructed happiness: domestic environment in the cold war era. Eesti Kunstiakadeemia, Tallinn, pp 239-252

Reklaitė J, Leitanaitė R (2011) Vilnius 1900-2012. Naujosios architektūros gidas, Baltos lankos, Vilnius

Rudberg E (1998) Building the welfare of the Folkhemmet 1940-60. In: Caldenby C et al (eds) Sweden: 20th century architecture. Prestel-Verlag, München

Tippel V (1963) Suur-Tallinna probleemidest. Linnaehituse küsimusi Eesti NSV-s. Eesti NSV Ministrite Nõukogu Riiklik Ehituse ja Arhitektuuri Komitee, Tallinn, pp 39-44

Tomberg T (1975) Таллин/Tallinn. Планета, Москва

Trentmann F (2012) Consumer society revisited: affluence, choice, and diversity. In: Langer L, Jessen R (eds) Transformations of retailing in Europe after 1945. Ashgate, Farnham, pp 19-32

Vanagas J (2008) Urbanistikos pagrindai. Technika, Vilnius

Vèlyvis J (1988) Mūsų medžiagos pèdsakais. Prekybos centrai Vilniuje. Klaidos kartojamos. Statyba ir architektūra 3:21

Vileikis A (1986) Vilnius - Tarybų Lietuvos sostinè. Mintis, Vilnius

Väljas M (2016) Karp, an architect with character. In: Karp R, Väljas M (eds) Arhitekt Raine Karp. Eesti Arhitektuurimuuseum, Tallinn, pp 9-36

Wakeman R (2016) Practicing utopia: an intellectual history of the new town movement. University of Chicago Press, Chicago

Yurchak A (2006) Everything was forever until it was no more. The last Soviet generation. Princeton University Press, Oxford

\section{Literature in Cyrillic Script}

Васильев Б. Л et al (1958) Города - спутники: Харлоу. Визеншо. Веллингбю: из опыта градостроительства за рубежом. Госстройиздат, Ленинград

Васильев Б (1960) Градостроительная практика и жилищное строительство в скандинавских странах: приемы планировки и застройки новых жилых районов. Госстройизда, Ленинград

Ико́нников А (1967) Хельсинки. Стройиздат, Ленинград

Ико́нников А (1978) Современная архитектура Швеции. Стройиздат, Москва 
Минкявичюс ЙК (1987) Архитектура советской Литвы. Стройиздат, Москва

Страутманис ИА et al (1987) Архитектура Советской Латвии. Architecture of the Soviet Latvia. Стройиздат, Москва

\section{Archival Materials}

Mustamäe ühiskondlike hoonete mahu paigutuse skeem (1966) Eesti Projekt, Tallinn (Estonian National Archives, ERA.T-14.4-6. 8818)

Open Access This chapter is licensed under the terms of the Creative Commons Attribution 4.0 International License (http://creativecommons.org/licenses/by/4.0/), which permits use, sharing, adaptation, distribution and reproduction in any medium or format, as long as you give appropriate credit to the original author(s) and the source, provide a link to the Creative Commons license and indicate if changes were made.

The images or other third party material in this chapter are included in the chapter's Creative Commons license, unless indicated otherwise in a credit line to the material. If material is not included in the chapter's Creative Commons license and your intended use is not permitted by statutory regulation or exceeds the permitted use, you will need to obtain permission directly from the copyright holder.

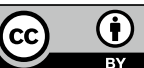

